\title{
Ocotea porosa: Anatomy and Histochemistry of Leaves and Stems, Chemical Composition, Cytotoxicity and Insecticidal Activities of Essential Oil
}

\author{
Libardone José Ribeiro Brustulim ${ }^{1}$ \\ https://orcid.org/0000-0002-1020-6948 \\ Luciane Mendes Monteiro ${ }^{1}$ \\ https://orcid.org/0000-0003-2896-8147 \\ Valter Paes de Almeida ${ }^{1}$ \\ https://orcid.org/0000-0003-0603-8184 \\ Vijayasankar Raman ${ }^{2}$ \\ https://orcid.org/0000-0001-7368-9644
}

\section{Beatriz Helena Lameiro de Noronha Sales \\ Maia $^{3}$}

https://orcid.org/0000-0001-5896-2892

\section{Inaiara Casapula ${ }^{3}$}

https://orcid.org/0000-0001-9758-3756

\author{
Kátia Sabrina Paludo ${ }^{1}$ \\ https://orcid.org/0000-0003-2248-5881
}

Julia Emília Bussade ${ }^{4}$

https://orcid.org/0000-0002-8516-5888

Junaid Ur Rehman ${ }^{2}$

https://orcid.org/0000-0002-5292-5457

Ikhlas Ahmed Kahn²

https://orcid.org/ 0000-0001-5464-4643

Paulo Vitor Farago ${ }^{1}$

https://orcid.org/0000-0002-9934-4027

Jane Manfron Budel ${ }^{1,2 *}$

https://orcid.org/0000-0003-1873-2253

${ }^{1}$ State University of Ponta Grossa, Health Science Graduate Program, Ponta Grossa, Paraná, Brazil; ${ }^{2}$ National Center for Natural Products Research, School of Pharmacy, University of Mississippi, University, MS, USA; ${ }^{3}$ Federal University of Paraná, Chemistry Department, Curitiba, Paraná, Brazil. ${ }^{4}$ University of Mississippi, Department of Modern Languages, University, MS, USA.

Received: 2019.09.11; Accepted:2020.02.10.

${ }^{*}$ Correspondence: janemanfron@hotmail.com; Tel.: +55-41-33203124 (J.M.B)

\section{HIGHLIGHTS}

- The anatomy features were useful for identification of Ocotea porosa.

- The major volatile compounds were $\alpha$-pinene, $\beta$-pinene and bicyclogermacrene.

- Essential oil of O. porosa was cytotoxic against McCoy, B16F10 and MCF7cell lines.

- The cytotoxic mechanism might be related to apoptotic events.

Abstract: Ocotea porosa (Nees \& Mart.) Barroso, commonly known as "imbuia", "canela-imbuia" or "imbuiaamarela" in Brazil, is a tree of the Southern Atlantic Forest. The present study investigates the anatomy of leaf and stem, volatile oil chemistry, as well as cytotoxicity and insecticidal activities of the essential oil of $O$. porosa. Species identification was achieved by anatomy features, mainly due to paracytic and anomocytic stomata; non-glandular trichomes; biconvex midrib and petiole with a collateral open arc vascular bundle; presence of a sclerenchymatous layer, starch grains and crystal sand in the stem; and the presence of 
phenolic compounds in the epidermis, phloem and xylem of the midrib, petiole and stem. The main volatile components of the essential oil were $\alpha$-pinene (19.71\%), $\beta$-pinene (13.86\%) and bicyclogermacrene (24.62\%). Cytotoxicity against human cancer cell (MCF-7), mouse cancer cell (B16F10) and mouse nontumoral cell (McCoy) was observed as well as insecticidal activity of the essential oil against susceptible 'Ft. Dix' bed bugs (Cimex lectularius L.) by topical application.

Keywords: anticancer; bed bugs; Cimex lectularius; cytotoxic effect; imbuia; light and scanning electron microscopy.

\section{INTRODUCTION}

Ocotea Aubl. is one of the most representative genus of Lauraceae comprising 428 species [1], with 168 of these species occurring in Brazil [2]. Ocotea porosa (Nees \& Mart.) Barroso and O. odorifera (Vell.) Rohwer are the most important Brazilian representatives of this genus [3]. The taxonomy and delimitation of Ocotea are problematic due to similar features with Cinnamomum Schaeff. and Nectandra Rol. ex Rottb. [4].

Several species of Ocotea have been reported to have important biological activities, such as antiherpetic [5], antimycobacterial [6], antibacterial [7], antinociceptive [8], antiplatelet and antithrombotic [9], acaricidal [10,11], anti-inflammatory [12], antiprotozoal activity against Trypanosoma cruzi and Leishmania [13], cytotoxic [14], antioxidant and antimutagenic activities [15]. The essential oils of Ocotea species have also exhibited promising antimicrobial activities against Escherichia coli and showed cytotoxicity against MCF-7 cells [9].

Monoterpenoids, sesquiterpenoids and phenylpropanoids were found in their essential oils [16,17]. Other metabolites such as benzylisoquinolinic and aporphinic alkaloids [18,19], lignans [20] were also described from the genus.

Ocotea porosa, usually called "imbuia", "imbuia-amarela", "imbuia-zebrina" in Brazil, is a typical tree species from Southern Atlantic Forest that reaches up to $15 \mathrm{~m}$ high. In spite of legal instruments that prevent the species exploitation, its wood is still considered as one of the most valuable for furniture and construction industry due to its moderately density and resistance to fungal infection [21]. This species is in danger of extinction due to overexploitation for wood extraction [2].

Considering the wide number of biological activities for essential oils from Ocotea, and the fact that no previous work was devoted to investigate the chemical composition of leaf essential oil and the anatomy of $O$. porosa, the present study aims to investigate the chemical profile of the volatile oil and its cytotoxic and insecticidal activities, as well as the anatomy of the leaf and stem of this species in order to provide accurate information to support the identification of plant materials.

\section{MATERIAL AND METHODS}

\section{Plant Material}

Fresh samples of leaves and stems of Ocotea porosa were collected from plants growing in open and

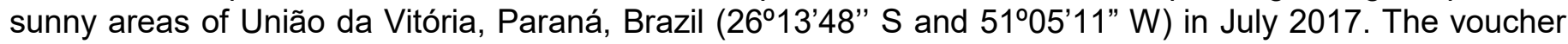
specimen was identified and deposited in the herbarium of State University of Ponta Grossa under number HUPG 22243. The access to botanical materials was authorized and licensed by the Genetic Heritage Administration Council (CGEN/SISGEN) according to code AD3F256.

At least six samples of mature leaves (cut from median, intercostal and margin regions) were obtained from the sixth node and below, as well as stem fragments 5 to $10 \mathrm{~cm}$ from the shoot were collected for anatomical analysis.

For the extraction of essential oil, the plant material was selected and standardized in order to acquire leaves and stems in the same pattern. The plant material was then dried in shade and cut into small pieces $(\sim 1 \mathrm{~cm})$.

\section{Microscopic procedure}

Freshly collected leaves and stems of $O$. porosa were fixed in formalin-acetic acid-alcohol (FAA) solution [22], for three days, washed in distilled water and then stored in $70 \%$ ethanol $(\mathrm{v} / \mathrm{v})$ [23] until use. Cross and longitudinal sections were freehand prepared using razor blades, placed on glass slides, hydrated, and stained with toluidine blue [24] or Astra blue and basic fuchsine combination [25]. Kraus and Arduin [26] methods were used to analyze epidermal features. 
Quantitative studies of stomata were performed by taking ten measurements from multiple leaf specimens. The length and width of stomata were measured from ten stomata at different places on the leaf blade for each species to determine the average stomatal size.

For the analysis by field emission scanning electron microscopy (FEG-SEM), the samples fixed in FAA were passed through a series of ethanol solutions of increasing concentrations and then dried in a critical point dryer (Balzers CPD-030) using liquid $\mathrm{CO}_{2}$. The dried samples were mounted on aluminum stubs using glued carbon tapes and then coated with gold using a Quorum SC7620 sputter coater [27]. Photomicrographs were prepared and examined using a Mira 3 Tescan FEG-SEM equipment located at the State University of Ponta Grossa (UEPG).

For histochemical tests, the following standard solutions were used: potassium dichromate (10\%) [28] and ferric chloride (2\%) [22] for phenolic compounds, phloroglucinol/HCl for lignin [29], Sudan III for lipophilic components [30], and iodine (1\%) for starch [23]. Controls were prepared in parallel with the tests and were carried out as described above. Photomicrographs were prepared using digital camera (C7070) attached to the light microscope (Olympus CX 31) at UEPG.

\section{Extraction of essential oil (EO) and GC-MS analysis}

Dried plant material $(300 \mathrm{~g})$ was subjected to hydrodistillation for $4 \mathrm{~h}$ in triplicate using a modified Clevenger-type apparatus for $\mathrm{EO}$ extraction. The obtained oil was dried using anhydrous $\mathrm{Na}_{2} \mathrm{SO}_{4}$ and kept in glass vials with Teflon-sealed caps at $4 \pm 0.5^{\circ} \mathrm{C}$ in absence of light.

The EO was analyzed using a Shimadzu GC-2010 Plus GC-MS/MS apparatus coupled to a TQ8040 triple quadrupole type tandem mass detector and AOC-5000 Plus automatic injector for analysis of liquid samples (headspace) and solid phase microextraction (SPME). The samples were diluted at $1 \%(v / v)$ in methylene chloride and characterized using the following analytical conditions: Rtx-5MS fused silica capillary column ( $5 \%$ diphenyl $+95 \%$ dimethylpolysiloxane $(30 \mathrm{~m} \times 0.25 \mathrm{~mm} \times 0.25 \mu \mathrm{m})$. The carrier gas used was helium at a flow rate of $1.02 \mathrm{~mL} / \mathrm{min}$, in $1: 90$ split mode. The injector was set at $250^{\circ} \mathrm{C}$ and the ionization system at $70 \mathrm{eV} .1 \mu \mathrm{L}$ of sample was injected into the following heating ramp: initial temperature $60^{\circ} \mathrm{C}$ to $250{ }^{\circ} \mathrm{C}$ with heating rate at $3{ }^{\circ} \mathrm{C} / \mathrm{min}$.

A homologous series of linear saturated hydrocarbons, C8 to C19 was used to calculate the retention index. The experimental retention index was obtained using the following Van den Dool and Kratz equation:

$$
\text { Retention index }=100 \times\left(C_{n}-C_{n-1}\right) \times\left(T_{x}-T_{n-1} / T_{n}-T_{n-1}\right)+100 \times C_{n-1}
$$

In the above equation, $C_{n}$ is the number of carbon atoms of the n-alkane whose retention time is immediately greater than the retention time of the analyte; $C_{n-1}$ is the number of carbon atoms of the n-alkane whose retention time is immediately less than the retention time of the analyte; $T_{x}$ is the retention time of the analyte; $T_{n}$ is the retention time of the $C_{n}$ alkane; $T_{n-1}$ is the retention time of the $C_{n-1}$ alkane.

The EO volatile components were identified by comparing retention indices and mass spectra with literature [31] and mass spectra were also compared with the NIST 02 mass library (NIST, Gaithersburg, MD, USA). The relative quantification was determined from the normalization of each peak area with the total chromatogram, with no use of any correction factor. This experimental was carried out at the Federal University of Paraná.

\section{Cell culture}

The human cancer cell (MCF-7, breast cancer, Rio de Janeiro cell bank n. 0162), mouse cancer cell (B16F10, melanoma, Rio de Janeiro cell bank n. 0342) and mouse non-tumoral cell (McCoy, fibroblast, Rio de Janeiro cell bank n. 0160) were maintained in RPMI 1640 medium ( $\mathrm{pH}$ 7.4) supplemented with 10\% fetal bovine serum (FBS), $24 \mathrm{mmol} / \mathrm{L}$ of sodium bicarbonate and $1 \%$ penicillin and streptomycin under controlled temperature $\left(37^{\circ} \mathrm{C}\right)$ and humidified atmosphere $\left(5 \% \mathrm{CO}_{2}\right)$. To cell and subcultures expansion, the same conditions were used.

\section{Cytotoxic assay}

This assay relies on the ability of viable cells to metabolically reduce a yellow tetrazolium salt (MTT) to a purple formazan product. This reaction takes place when mitochondrial reductases are active [32]. Cells were placed in 96 wells plates $\left(4 \times 10^{3}\right.$ cell $/$ well). After $24 \mathrm{~h}$, aliquots of $O$. porosa EO ranging from $0.77 \mu \mathrm{g} / \mathrm{mL}$ to $77 \mathrm{mg} / \mathrm{mL}$ dissolved in RPMI were added upon each cell and incubated for $72 \mathrm{~h}$. The medium was 
removed, replaced with $100 \mu \mathrm{L}$ of MTT solution $(0.5 \mathrm{mg} / \mathrm{mL})$ and incubated at $37^{\circ} \mathrm{C}$ for $2 \mathrm{~h}$. After this period of incubation, the resulting formazan crystals were solubilized in isopropyl alcohol acid and the optical density was red at $550 \mathrm{~nm}$ using an Elisa plate reader. The negative control was prepared as described above, but each cell was only incubated using RPMI medium. Tests were performed in quadruplicate and repeated three times.

\section{$I C_{50}$ and selectivity index}

$\mathrm{IC}_{50}$ were determined using logarithmic dose-response sigmoidal curves based on nonlinear regression (using GraphPad Prism software). The selectivity index ( $\mathrm{SI}$ ) was calculated as the ratio $\mathrm{IC}_{50}$ (control cells McCoy)/IC 50 (tumor cell lines - B6F10 or MCF-7). A selectivity index $>1$ indicates that the cytotoxicity on cancer cells surpassed the one on the healthy non-tumor cells.

\section{Morphological study}

Cells $\left(3 \times 10^{3}\right.$ cell/well) were seeded in 24-well plates containing a coverslip on the bottom, and incubated at $37{ }^{\circ} \mathrm{C}$ and $5 \% \mathrm{CO}_{2}$ for $24 \mathrm{~h}$. After this time, the cells were treated with O. porosa $\mathrm{EO}(77 \mu \mathrm{g} / \mathrm{mL})$, and incubated for $24 \mathrm{~h}$. After that the culture medium was removed, washed with PBS, fixed with $2 \%$ formaldehyde for 2 min and stained with May-Grünwald stain. Coverslips were mounted and observed under a microscope coupled to a digital camera.

\section{Insecticidal activity studies}

Strains of Cimex lectularius, Bayonne (insecticide resistant) and Ft. Dix (susceptible) were provided by Dr. Changlu Wang, Department of Entomology, Rutgers University, New Brunswick, NJ, and their colony was raised using blood feeders (CG-1836-75 ChemGlass). The insecticidal activity of $O$. porosa EO against bed bugs was assessed by fumigation, topical application, and residual studies.

For fumigation study, bed bugs were exposed to vapor toxicity in $125 \mathrm{~mL}$ clear glass jars. A small piece of paper was placed in the jar's bottom to deliver a substrate for the bed bugs to rest during the tests. Bed bugs were introduced in the jars $2-4 \mathrm{~h}$ before treatment to acclimatize. A treatment solution or acetone aliquot of $2 \mu \mathrm{L}$ was located directly onto the internal surface of the bottle side wall $\sim 4 \mathrm{~cm}$ from bottle bottom using a $50 \mu \mathrm{L}$ gas-tight syringe (Hamilton Company, Reno, NV) attached to a PB600 (Hamilton Company, Reno, NV) repeating dispense. Five concentrations viz., 15.6, 31.25, 62.5, 125 and $250 \mu \mathrm{g} \mathrm{EO} / 125 \mathrm{sq} . \mathrm{cm}$ were tested against the bed bugs. The jars were placed in the growth chamber and data for mortality were verified $24 \mathrm{~h}$ after the treatment. The 2,2-diclorovinil-dimetylphosphate (DDVP) was used as the standard.

Studies using $O$. porosa EO in topical application were carried out with adult insects, which were separated in the Petri dishes and anesthetized with $\mathrm{CO}_{2} .1 \mu \mathrm{L}$ of treatment solution $(50 \mu \mathrm{g} / \mathrm{bug})$ in acetone was carried onto the dorsal surface of the abdomen, using a hand-held repeating dispenser. Control bugs received $1 \mu \mathrm{L}$ of acetone alone. Data for the mortality of the bed bugs were verified for seven days after treatment. There were three replicates with ten bugs (mixed sex)/replicate. The standard was deltamethrin (2.4 ng/bug).

For residual studies, an aliquot of $100 \mu \mathrm{L}$ of treatment (diluted in acetone) was applied on $20 \mathrm{~cm}^{2}$ Whatman \#1 filter paper achieving $100 \mu \mathrm{g} / \mathrm{cm}^{2}$ of residues. The treated filter papers were then placed in the Petri dish. Only acetone was used in control tests. Ten adult bed bugs were released on the filter paper and mortality was recorded as mentioned in topical application. Deltamethrin was used as standard insecticide.

\section{Statistical analysis}

Cytotoxicity assays were analyzed by the difference of experimental statistical significance using analysis of variance (ANOVA) followed by Tukey's test. The experimental values were expressed as the mean \pm standard error of the mean. The data were analyzed using Graph Pad Prism 7.0 software. The level of $p<0.05$ was used to determine statistical significance.

Treatment means of vapor toxicity were compared using two factor analysis of variance (ANOVA) and separated by Tukey's honestly significant difference (HSD). Analysis were performed in SAS® 9.3 and JMP®10.0. 


\section{RESULTS AND DISCUSSION}

\section{Microscopical analysis}

Ocotea porosa (Figure $1 \mathrm{~A}, \mathrm{~B}$ ) leaves have domatia in the nerve axils beneath (Figure $1 \mathrm{D}$ ). This feature has also been observed in other species, such as 0 . urbaniana Mez, O. pulchella (Nees \& Mart.) Mez, $O$. tristis (Nees \& Mart.) Mez and O. catharinensis Mez [33].

From the surface view, the leaf possesses straight anticlinal cell walls on adaxial side and wavy on abaxial epidermis (Figure $1 \mathrm{C}, \mathrm{E}$ ). This feature is also found in $O$. puberula (Rich.) Nees [34]. However, $O$. indecora (Schott) Mez had sinuous anticlinal walls on both sides [35] whereas O. gardneri (Meisn.) Mez had both epidermises with straight anticlinal cell walls [36]. This is a significant feature in distinguishing various species of Ocotea.

Epicuticular waxes are found on the epidermis, especially on the stomata (Figure $1 \mathrm{G}, \mathrm{H}$ ). This characteristic was not mentioned for other species of Ocotea. The stomata are of paracytic or anomocytic types (Figure $1 \mathrm{E}$ ) and the leaves are hipostomatic as also reported for several other Ocotea species [7,3539]. The average size of stomata is $29 \times 23 \mu \mathrm{m}$. The stomatal index calculated for $O$. porosa is 16.43 per unit area $(1 \mathrm{sq} . \mathrm{mm})$ on the abaxial side.

Ocotea porosa evidences simple unicellular non-glandular trichomes on both surfaces although rarely on the adaxial side (Figure $1 \mathrm{~F}, \mathrm{G}$ ). Similar trichomes have also been reported for $O$. puberula [34] and $O$. indecora [35]. Even though this feature is common in the taxa of Lauraceae [35], O. gardneri had glabrous leaves [36].
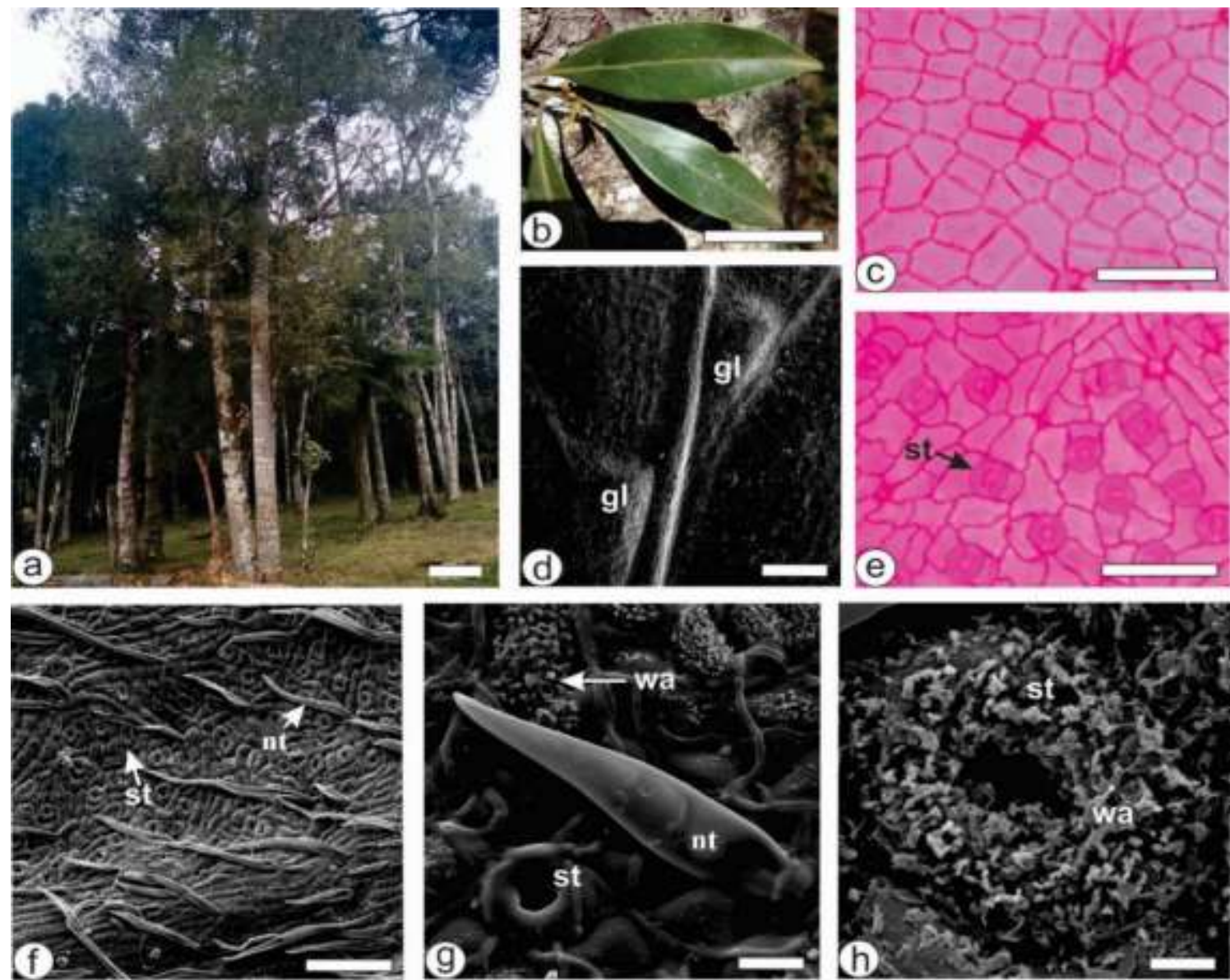

Figure 1. Morpho-anatomy of Ocotea porosa [c, e: Light microscopy; $d, f, g$, h: FEG-SEM]. a- Plant in habit. b- Leaves. $\mathrm{c}$-h- Leaf in surface view (c- adaxial, e-h- abaxial). [gl-domatia of glands, st- stomata, nt- non-glandular trichome, wawaxes]. Scale bar: $a=70 \mathrm{~cm} ; b=4 \mathrm{~cm} ; d=1 \mathrm{~mm} ; \mathrm{f}=100 \mu \mathrm{m} ; \mathrm{c}, \mathrm{e}=50 \mu \mathrm{m} ; \mathrm{g}=20 \mu \mathrm{m} ; \mathrm{h}=5 \mu \mathrm{m}$.

In transverse section (TS) of the leaf, the epidermis is uniseriate (Figure $2 \mathrm{~A}, \mathrm{~B}$ ) and the cells contain phenolic compounds that reacted positively for histochemical tests. Epidermis is covered by a thin cuticle that reacted for Sudan III. The leaf is dorsiventral and is formed by two layers of palisade and 5-6 layers of spongy parenchyma (Figure $2 \mathrm{~B}, \mathrm{C}$ ). The veinlets traversing the mesophyll region are represented by small collateral 
vascular bundles surrounded by sclerenchymatous sheath with extensions that reach both faces of the epidermis (Figure 2 B). Dorsiventral mesophyll is frequent in the family Lauraceae [40]. However, O. gardneri evidenced isobilateral mesophyll [36].

The edge of the lamina is slightly curved downwards. The epidermis possesses cells with irregular shape and covered by thick cuticle. Underneath the epidermis many layers of sclerenchyma cells are found (Figure 2 A). These characteristics have also been observed in O. gardneri [36].

Secretory cells with spherical to oblong shape (Figure 2 B) and with light yellow lipophilic contents reacted with Sudan III in the histochemical test (Figure $3 \mathrm{~A}$ ) are found in the lamina, especially in the adaxial side as well as in the midrib regions. Secretory cells are widely reported in the species of Ocotea [34-39].

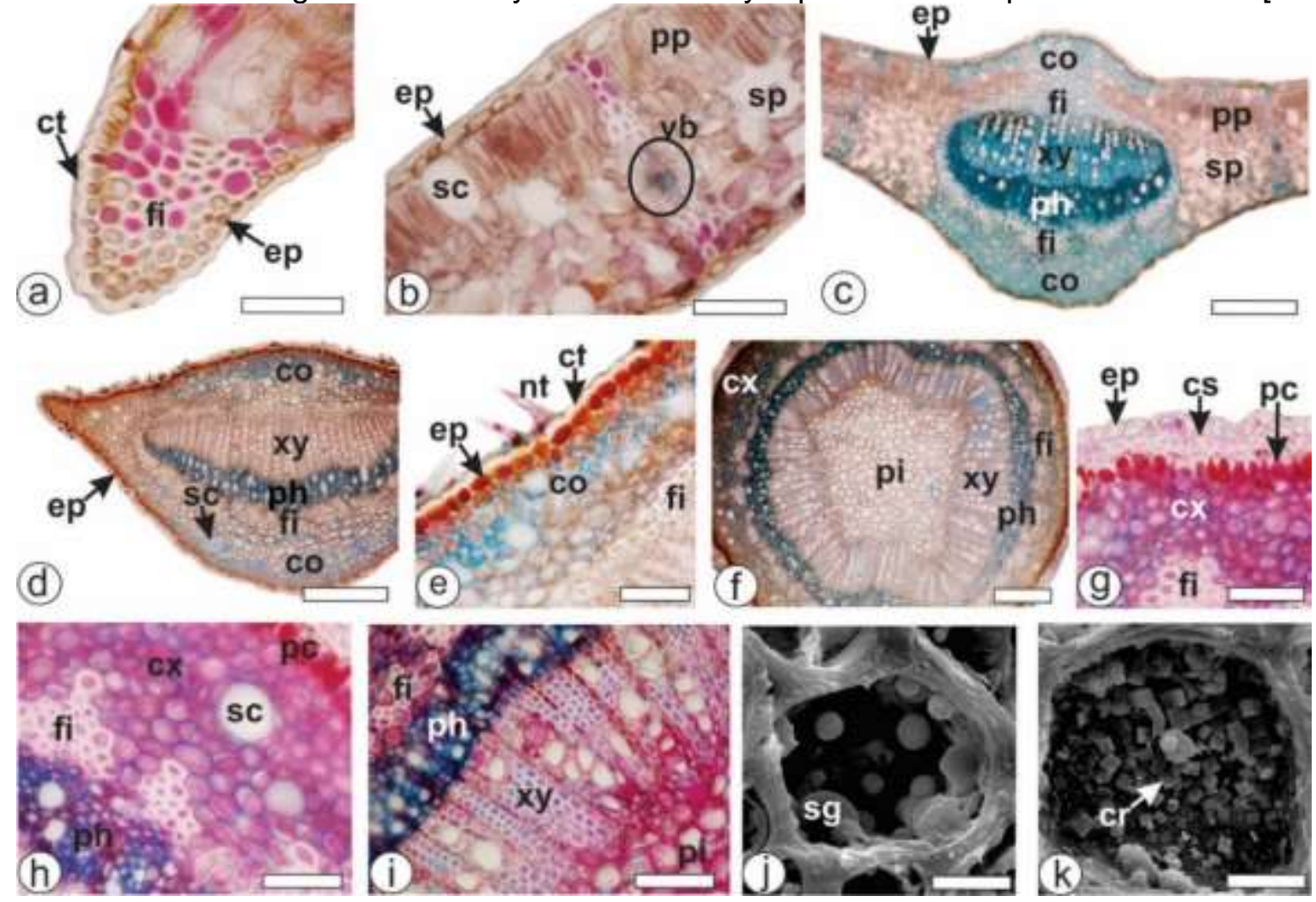

Figure 2. Anatomy of Ocotea porosa leaves and stems [a-i: Light microscopy; j, k: FEG-SEM]. a. TS through leaf margin; b. TS of lamina; c. TS of midrib and lamina; $d$ and e. TS of petiole; f-k. TS of stem. [co- collenchyma, cr- crystals, cssubepidermal layer, ct- cuticle, cx- cortex, ep- epidermis, fi- fibers, nt- non-glandular trichome, pc- phenolic compounds, sc- secretory cell, sg- starch grains, ph- phloem, pp- palisade parenchyma, pi- pith, sp- spongy parenchyma, vbvascular bundle, $x y-x y l e m]$. Scale bar: $a, b, e, g, h, i=50 \mu \mathrm{m} ; c, d, f=200 \mu \mathrm{m} ; k=10 \mu \mathrm{m} ; j=5 \mu \mathrm{m}$.

In transverse section, the midrib is biconvex in outline (Figure $2 \mathrm{C}$ ). This characteristic has also been observed in O. odorifera (Vell.) Rohwer [37], O. puberula [34], O. indecora [35] and O. gardneri [36]. The uniseriate epidermis is formed by cells with different shapes and sizes containing phenolic compounds which reacted with ferric chloride (Figure $3 \mathrm{D}$ ). The epidermis is covered by a thick cuticle evidenced by Sudan III in the histochemical tests (Figure $3 \mathrm{~A}$ ). Beneath the epidermis several layers of annular collenchyma are found. Annular collenchyma was also found in O. odorifera [37] whereas the angular type was observed in O. puberula [34].

The vascular system of the midrib is represented by one collateral vascular bundle in open arc that is surrounded by a continuous sheath of sclerenchymatous fibers (Figures 2 C, 3 A-D) which reacted with phloroglucinol/HCl (Figure $3 \mathrm{~B}$ ). Phenolic compounds are found in some cells of xylem and in several cells of phloem. These compounds are evidenced in the histochemical tests using potassium dichromate $10 \%$ (Figure $3 \mathrm{C}$ ). Idioblasts containing phenolic compounds were also found in the midrib of 0 . odorifera [37] and O. puberula [34].

The petiole, in cross-section, varies from biconvex shape with two lateral extensions in the distal region (Figure $2 \mathrm{D}$ ), flat-convex in the medial region (Figure $3 \mathrm{E}$ ) to cylindrical in the proximal region. This pattern has also been observed in O. diospyrifolia (Meisn.) Mez, O. pulchella (Nees \& Mart.) Mezand, O. tristis (Ness \& Mart.) Mez in the proximal region. However, biconvex shape with two lateral extensions occurred in the median and distal regions of $O$. pulchella, whereas flat-convex shape was found in the same regions in $O$. 
tristis [33]. The petiole shape can help the Ocotea species identification as observed in Passiflora L. [41] and Mikania Willd. [42].

The epidermis is unilayered and covered by thick cuticle (Figure $3 \mathrm{E}$ ) and has numerous non-glandular trichomes. Underneath the epidermis, several layers of annular collenchyma are observed on both sides (Figure $3 \mathrm{E}$ ). Some secretory cells are distributed in the petiole (Figure $3 \mathrm{~F}$ ). Ocotea gardneri showed similar non-glandular trichomes only in the petiole [36].
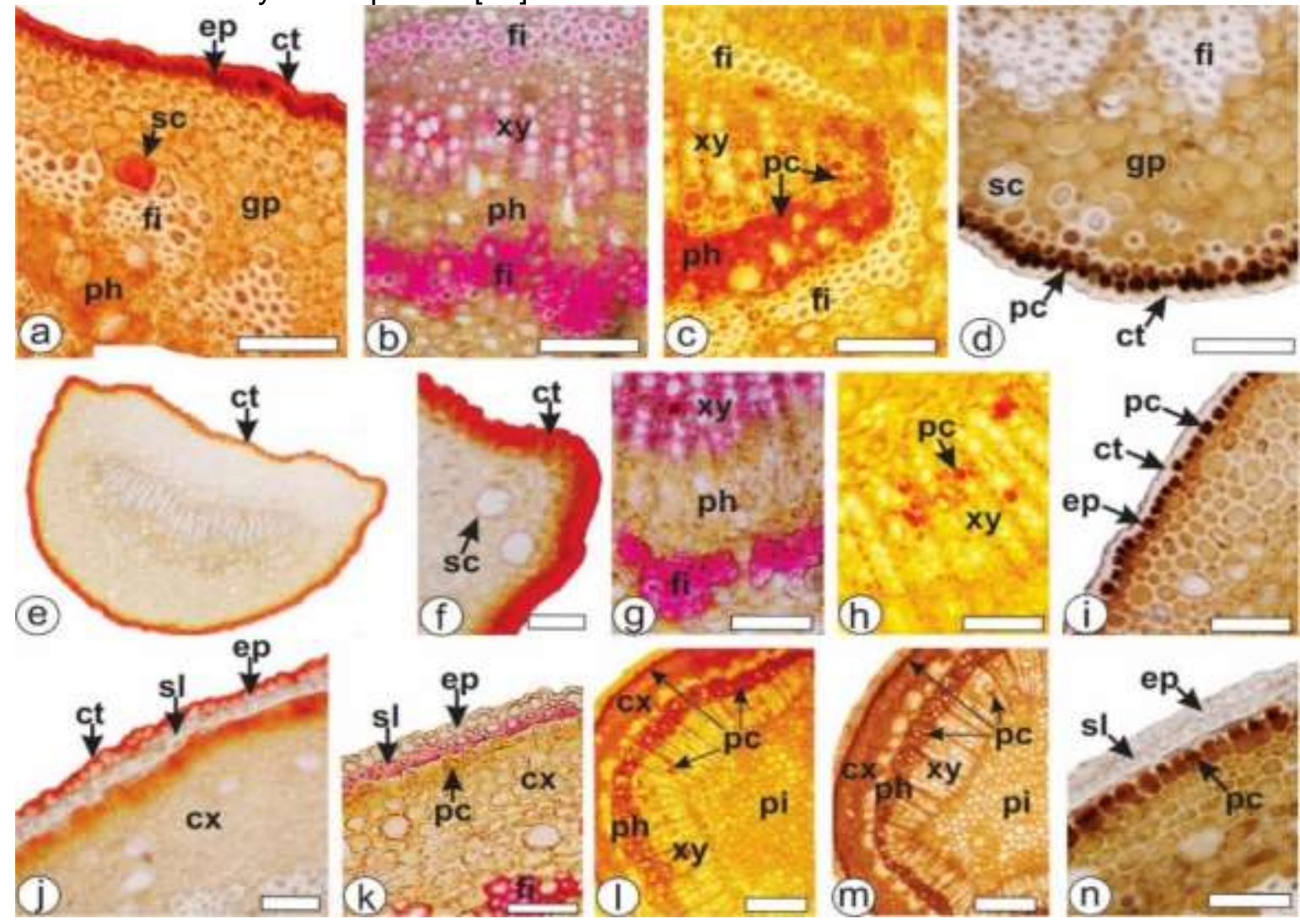

Figure 3. Histochemistry of Ocotea porosa [a, e, f, j: Sudan III; b, g, k: phloroglucinol/HCl; d, i, m, n: ferric chloride (2\%); c, h, I: potassium dichromate solution (10\%). Transverse sections. a-d: midrib; e-i: petiole; j-n: stem [ct, cuticle; cx, cortex; en, endodermis; ep, epidermis; fi: fibers, gp, ground parenchyma; pc, phenolic compounds; ph, phloem; pi, pith; sc, secretory cavity; sl, sclerenchymatous layer; $x y, x y l e m]$. Scale bars: $a-d$, f-k $=50 \mu \mathrm{m}, \mathrm{e}=200 \mu \mathrm{m}, \mathrm{l}, \mathrm{m}=100 \mu \mathrm{m}$.

In an incipient secondary structure, the stem is circular in shape (Figure $2 \mathrm{~F}$ ). The epidermis is uniseriate and covered by a thin cuticle. Beneath the epidermis, a layer of sclerenchymatous cells (Figure $2 \mathrm{G}$ ) and a layer of cells containing phenolic compounds are found (Figure $2 \mathrm{G}, \mathrm{H}$ ). The cortical parenchyma presents 10-12 layers (Figure $2 \mathrm{G}, \mathrm{H}$ ). Secretory idioblasts are also present in the cortex (Figure $2 \mathrm{H}$ ). The vascular system has phloem towards the periphery, and xylem facing the pith, separated by a cambium (Figure $2 \mathrm{I}$ ). Perivascular fiber patches are adjoined to the phloem (Figure 2G-I). The fibers and xylem are reacted with phloroglucinol/ $\mathrm{HCl}$ and stained pink evidencing lignification in the walls (Figure $3 \mathrm{~K}$ ). The pith is made up of thin-walled parenchymatous cells. Starch grains (Figure $2 \mathrm{~J}$ ) and sand crystals are found (Figure $2 \mathrm{~K}$ ) in the pith region.

\section{Yield and chemical composition of essential oil (EO)}

The EO of $O$. porosa presents a light-yellow color and a strong and characteristic aroma. The light-yellow coloration is common to several Ocotea species [17]. The yield of $O$. porosa EO is $1.03 \%$. The species $O$. caudata (Nees) Mez, O. cujumary Mart. and O. canaliculata (Rich.) Mez, which were collected in the National Forest of Caxiuanã, Amazonas, Brazil, presented an average yield of $0.8 \%$ [7]. In the present study, leaves were used for EO extraction. The anatomical study evidenced several secretory cavities (Figures. 2 B, 3 A, $\mathrm{D}, \mathrm{F})$ that store $\mathrm{EO}$ in the leaf blade and petiole.

The chemical composition of the EO extracted from $O$. porosa leaves was analyzed by GC-MS and is summarized in Table 1. Comparing the groups, O. porosa EO has $38.19 \%$ of monoterpenoid hydrocarbons, $1.02 \%$ of oxygenated monoterpenoids, $35.21 \%$ of sesquiterpenoid hydrocarbons and $18.20 \%$ of oxygenated 
sesquiterpenoids. High concentrations of sesquiterpenoids were also found in other species of Ocotea, such as O. gomezii W.C. Burger and O. morae Gómez-Laur [43].

Table 1. Chemical composition of Ocotea porosa essential oil.

\begin{tabular}{|c|c|c|c|c|c|}
\hline$\#$ & $\mathbf{R t}$ & $\mathrm{Al}^{1}$ & $\overline{A l^{2}}$ & Chemical compound & $\%$ \\
\hline 1 & 6.080 & 933 & 932 & $\alpha$-Pinene & 19.71 \\
\hline 2 & 6.544 & 947 & 946 & Camphene & 0.48 \\
\hline 3 & 7.354 & 973 & 969 & Sabinene & 0.60 \\
\hline 4 & 7.464 & 976 & 974 & $\beta$-Pinene & 13.86 \\
\hline 5 & 7.954 & 991 & 988 & Mircene & 2.07 \\
\hline 6 & 8.908 & 1017 & 1014 & $\alpha$-Terpinene & 0.25 \\
\hline 7 & 9.368 & 1028 & 1024 & Limonene & 0.78 \\
\hline 8 & 9.459 & 1031 & 1026 & 1,8-Cineole & 0.24 \\
\hline 9 & 10.581 & 1059 & 1054 & $y$-Terpinene & 0.36 \\
\hline 10 & 15.640 & 1177 & 1174 & Terpinen-4-ol & 0.43 \\
\hline 11 & 16.248 & 1191 & 1186 & $\alpha$-Terpineol & 0.35 \\
\hline 12 & 24.286 & 1376 & 1374 & $\alpha$-Copaene & 0.34 \\
\hline 13 & 24.661 & 1385 & 1387 & $\beta$-Bourbolene & 0.53 \\
\hline 14 & 24.994 & 1392 & 1389 & $\beta$-Elemene & 0,51 \\
\hline 15 & 26.100 & 1419 & 1417 & $(E)$-Caryophyllene & 1.70 \\
\hline 16 & 26.905 & 1439 & 1440 & Aromadendrene & 0.86 \\
\hline 17 & 27.491 & 1453 & 1452 & $\alpha$-Humulene & 0.57 \\
\hline 18 & 27.799 & 1461 & 1458 & Allo-aromadendrene & 1.98 \\
\hline 19 & 28.626 & 1481 & 1484 & Germacrene D & 1.88 \\
\hline 20 & 29.266 & 1497 & 1500 & Biciclogermacrene & 24.62 \\
\hline 21 & 29.959 & 1515 & 1513 & $y$-Cadinene & 1,17 \\
\hline 22 & 30.346 & 1525 & 1522 & $\delta$-Cadinene & 0.66 \\
\hline 23 & 31.331 & 1550 & 1548 & Elemol & 0.74 \\
\hline 24 & 31.620 & 1558 & 1559 & Germacrene B & 0.39 \\
\hline 25 & 32.415 & 1578 & 1577 & Spathulenol & 5.34 \\
\hline 26 & 32.650 & 1584 & 1590 & Globulol & 2.09 \\
\hline 27 & 32.951 & 1592 & 1592 & Viridiflorol & 0.99 \\
\hline 28 & 33.207 & 1599 & 1600 & Guaiol & 1.95 \\
\hline 29 & 33.846 & 1616 & 1618 & 1,10-di-epi-cubenol & 0.95 \\
\hline 30 & 34.470 & 1633 & 1630 & $y$-Eudesmol & 0.42 \\
\hline 31 & 34.716 & 1640 & 1639 & alloaromadendrene epoxide & 0.72 \\
\hline 32 & 35.136 & 1651 & 1649 & $\beta$-Eudesmol & 1.77 \\
\hline 33 & 35.251 & 1654 & 1652 & $\alpha$-Eudesmol & 1.09 \\
\hline 34 & 35.418 & 1659 & 1656 & Valerianol & 1.40 \\
\hline 35 & 35.797 & 1669 & 1670 & Bulnesol & 0.75 \\
\hline \multicolumn{5}{|c|}{ Classes of } & $\begin{array}{c}\% \\
38.12\end{array}$ \\
\hline \multicolumn{5}{|c|}{ Oxygenated Monoterpenoids } & 1.02 \\
\hline \multicolumn{5}{|c|}{ Sesquiterpenoids hydrocarbons } & 35.21 \\
\hline \multicolumn{5}{|c|}{ Oxygenated Sesquiterpenoids } & 18.20 \\
\hline \multicolumn{5}{|c|}{ Total } & 92.54 \\
\hline
\end{tabular}

Rt: Retention time of calculated compounds compared to n-alkanes in HP-5MS column. \%: abundance of essential oil components. ${ }^{1}$ Calculated retention index. ${ }^{2}$ Literature retention index [31]. Compounds of concentration $>0.2 \%$ were identified. The major compounds are highlighted in bold.

Thirty-five volatile compounds (92.54\%) of EO of $O$. porosa were identified. The major compounds were bicyclogermacrene (24.62\%), $\alpha$-pinene (19.71\%) and $\beta$-pinene (13.86\%). Weyerstahl and coworkers [44] verified a distinct chemical composition for the $\mathrm{EO}$ of $O$. porosa extracted from the wood. These authors found carquejila acetate $(2.1 \%), \alpha$-copaene $(5.6 \%), \gamma$-copaene $(3.5 \%), \delta$-cadinene $(3.1 \%)$, cremoligenol (8.4\%), $\beta$-eudesmol (8.4\%), valerianol (5\%), $\alpha$-bisabolol $(3.6 \%)$ and $\beta$-bisabolol $(2.9 \%)$ as the major compounds of EO derived from the wood. Reynolds and coworkers [45] analyzed EO extracted from $O$. porosa stem barks and found as major components $\alpha$-copaene $(6.25 \%)$, $\delta$-cadinene $(3.28 \%), \beta$-eudesmol $(6.86 \%)$, valerianol $(7.55 \%)$ and $\alpha$-bisabolol (3.33\%).

In the present study, the differences found in the chemical composition of $O$. porosa in relation to the literature data occurred due to the fact that EO was obtained from leaves and not from wood or stem barks. In addition, not only the composition of EO, but also the concentrations of the compounds vary depending on 
the age of the plant as well as other factors, such as circadian rhythms, seasonal conditions and environmental influences [46]. Takaku and coauthors [17] analyzed the volatile components of leaves of several Ocotea species from Costa Rica, namely O. floribunda (Sw.) Mez, O. holdridgeana W.C.Burger, $O$. meziana C.K.Allen, O. sinuata (Mez) Rohwer, O. tonduzii Standl, O. valerioana (Standl.) W.C.Burger, O. veraguensis (Meisn.) Mez, and $O$. whitei Woodson. The most common volatile compounds among these species were $\alpha$-pinene, $\beta$-pinene, $\beta$-caryophyllene and germacrene $\mathrm{D}$. In the present study, $\alpha$-pinene and $\beta$ pinene were present in high concentrations.

Considering the biological activities, the chemical composition of EO is extremely important and should be evaluated [10]. In the present study, bicyclogermacrene, the most abundant compound in EO of $O$. porosa, showed a larvicidal action on the vectors of malaria, dengue, Japanese encephalitis [47] and fungicide activities [9].

The volatile compounds $\alpha$-pinene and $\beta$-pinene were also found in high concentrations in the present study and have been evaluated for biological activities. Both compounds presented antibacterial, antiviral, antifungal and hypotensive activities [48], $\alpha$-pinene presented anti-inflammatory, hypoglycemic [49], and gastroprotective activities [50] whereas $\beta$-pinene showed antidepressant [51] and antiviral [52] properties.

\section{Insecticidal activities}

Ocotea porosa EO was exposed to toxicity test against two strains of Cimex lectularius (Insecticide resistant 'Bayonne' and susceptible 'Ft. Dix') using three delivery methods i.e topical, residual and fumigation. The EO of O. porosa (100 $\mu \mathrm{g} / \mathrm{bug})$ produced $13.3 \%$ mortality in Ft. Dix strain that could reach to $23.3 \% 7$ days after treatment, whereas no mortality was recorded in Bayonne strain. EO of O. porosa was not toxic to bed bugs in fumigation ( $250 \mu \mathrm{g} / 125 \mathrm{~mL}$ of air) and residual $(100 \mu \mathrm{g} / \mathrm{cm} . \mathrm{sq}$.) assays. Using the same methods, EO of Baccharis sphenophylla Dusén ex Malme produced $66.67 \pm 3.33 \%$ mortality in the insecticide-resistant strain 'Bayonne', while producing $83.33 \pm 3.33 \%$ mortality in the susceptible strain 'Ft.Dix', $24 \mathrm{~h}$ after treatment [53]. The EO of Schinus molle L. produced $100.0 \pm 0.00 \%$ (Ft. Dix) and $90.0 \pm 5.77 \%$ (Bayonne) of mortality $24 \mathrm{~h}$ after the treatment [54]. In that sense, O. porosa EO cannot be considered as an effective insecticide against bed bugs.

\section{Cytotoxicity activities}

There are no reports of the activities of $O$. porosa EO against melanoma and breast cancer cell lines or the possible mechanisms related to these activities. Thus, an initial evaluation of the cytotoxicity effect of $O$. porosa EO against MCF-7 and B16F10 cells lines was performed (Figure 4) by an MTT reduction assay, and the $\mathrm{IC}_{50}$ and $\mathrm{SI}$ (selectivity index) values are presented in Table 2. Ocotea porosa EO showed cytotoxic effects against all cell lines tested at different concentrations with the lowest $I_{50}$ value achieved after $72 \mathrm{~h}$ of treatment.

Statistically significant results were obtained for MCF-7 and B16F10 cells up to the concentration of 7 $\mu \mathrm{g} / \mathrm{mL}$. McCoy cells presented cytotoxicity with statistical difference to the control until $77 \mu \mathrm{g} / \mathrm{mL}$. Essential oils of $O$. caudata, $O$. cujumary and $O$. caniculata displayed promising cytotoxic activities against MCF-7 cells showing median inhibitory concentration $\left(\mathrm{IC}_{50}\right) \sim=65.0 \mu \mathrm{g} \cdot \mathrm{mL}^{-1}$ [9]. The major compounds found in the present study, $\alpha$-pinene, $\beta$-pinene and bicyclogermacrene also showed cytotoxic activities against MCF-7 cells in a study by Grecco and coworkers [55]. Taking all these into account, EO of $O$. porosa can be further investigated regarding both selectivity and cytotoxic mechanisms.

However, an ideal anticancer drug must produce a cytotoxic effect for cancer cells in low concentrations without affecting normal cells. Ashley and coworkers [56] suggested that for a compound to be considered of low toxicity and has good chances of became a new anticancer drug, it should present an SI higher than 2. The results showed in Table 2 presented an SI of 1.05 and 0.05 for B16F10 and MCF-7 when compared to fibroblast normal cells (McCoyline), respectively. These data restrict possible use of EO from $O$. porosa as novel anticancer product. However, these values may be improved after EO fractionation and isolation of more suitable compounds. 

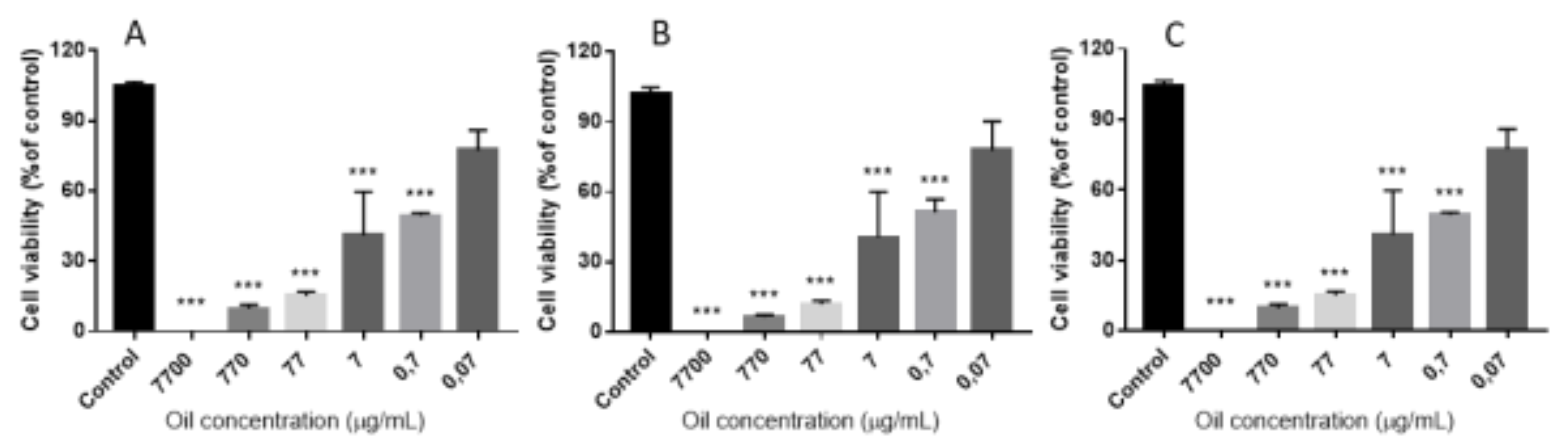

Figure 4. Cell cytotoxicity was determined using MTT assay. A - MCF-7, B - B16F10 and C - McCoy cells. ${ }^{* *} p<0.01$ and ${ }^{* * *} p<0.001$ compared to control. One-way ANOVA with Tukey's post hoc test. Three independent experiments were performed.

Table 2. I $\mathrm{I}_{50}$ values of $O$. porosa oil for different cell lines and selectivity index (SI). IC $\mathrm{C}_{50}$ data were expressed as mean and \pm standard error of the mean of three independent experiments.

\begin{tabular}{ccc}
\hline Cell lineage & $\mathbf{I C}_{50}(\mathbf{m g} / \mathbf{m L})$ & SI \\
\hline McCoy & $9.23 \pm 7.04$ & - \\
B16F10 & $8.82 \pm 6.27$ & 1.05 \\
MCF-7 & $185.4 \pm 10.91$ & 0.05 \\
\hline
\end{tabular}

The morphological features of MCF-7 and B16F10 cell lines were also investigated by studying the effects of $O$. porosa EO on cells $(77 \mu \mathrm{g} / \mathrm{mL}$, for $24 \mathrm{~h})$. EO of $O$. porosa induced cell death with apoptotic characteristics as cell rounding, membrane blebbing and chromatin condensation (Figure 5). Apoptosis and necrosis are the two major processes leading to cell death. Apoptosis occurs under normal physiological conditions and the cell is an active participant in its own demise. Due to this efficient mechanism for the removal of apoptotic cells, no inflammatory response is elicited [57]. These results suggest that EO of $O$. porosa provides a more suitable cell death mechanism than other essential oils as EO of Baccharis milleflora (Less.) DC. [57] and Lavandula dentata L. [58] which promoted necrotic and apoptotic processes, simultaneously.
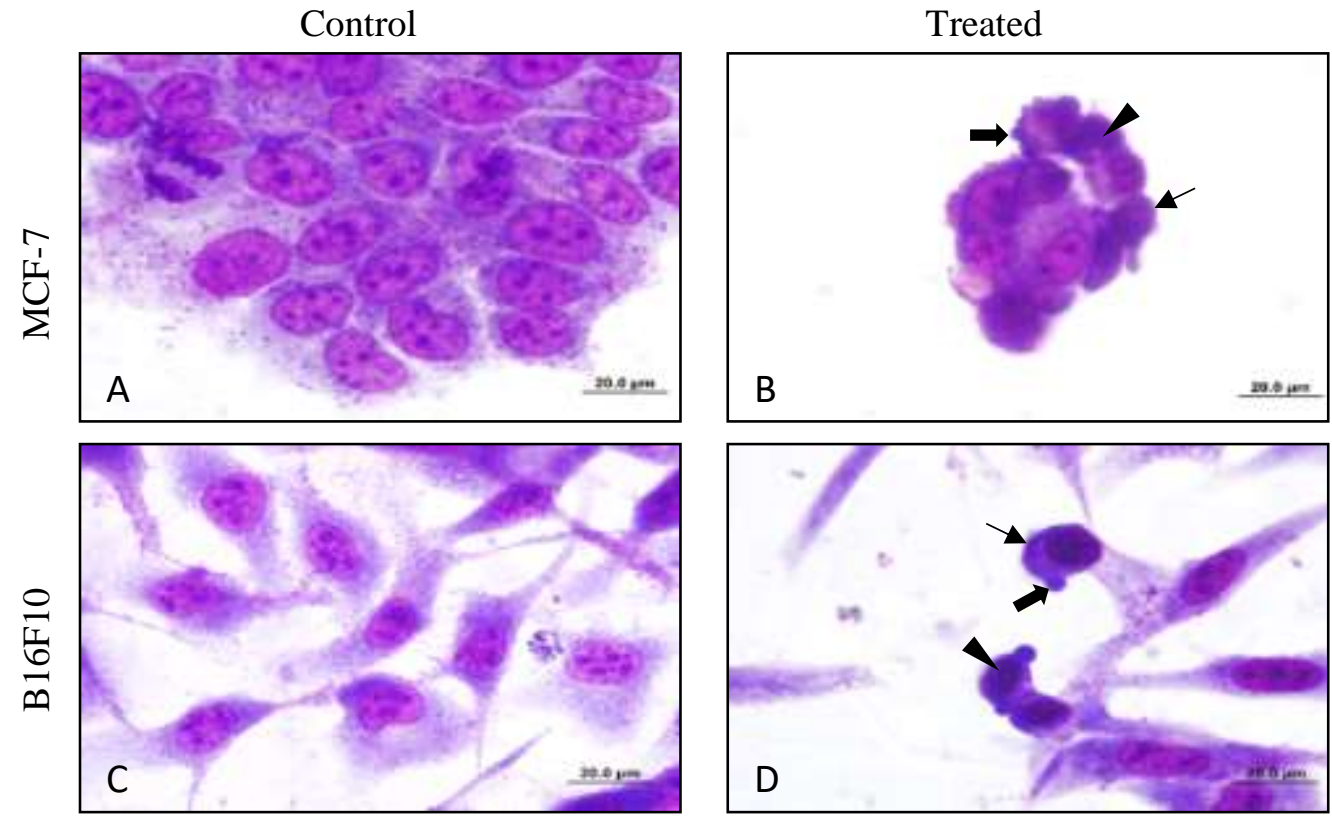

Figure 5. Morphology of MCF-7and B16F10 cells after $24 \mathrm{~h}$ of treatment with O. porosa EO. A and C - Control cells incubated with RPMI only. B and D - cells treated with $77 \mu \mathrm{g} / \mathrm{mL}$ of $O$. porosa EO. $\uparrow$ : cell rounding, $\boldsymbol{-}$ : bleb formation, $\Delta$ : chromatin condensation. Magnification $=1000 x$, bar $=20 \mu \mathrm{m}$.

\section{CONCLUSION}

In the present work, the chemical profiles of Ocotea porosa EO were analyzed. The volatile compositions of $\mathrm{EO}$ of the leaves were reported for the first time. The major volatile compounds were $\alpha$-pinene, $\beta$-pinene 
and bicyclogermacrene. EO of $O$. porosa demonstrated $13.3 \%$ mortality in Ft. Dix strain of bed bugs that could reach to $23.3 \% 7$ days after treatment, while no mortality was recorded in Bayonne strain. EO of $O$. porosa was not toxic to bed bugs in fumigation and residual assays. The EO of $O$. porosa was cytotoxic to murine fibroblast cell lines (McCoy), murine melanoma (B16F10) and human breast adenocarcinoma (MCF7) probably by apoptosis. However, there was no evidence of selectivity against the tumor cells under study. The anatomical characteristics that were observed in this study may help in the correct identification of $O$. porosa. Noteworthy anatomical features include the hypostomatic leaves with paracytic and anomocytic stomata; epicuticular wax, especially on the stomata; non-glandular trichomes; biconvex midrib and petiole with a collateral open arc vascular bundle; presence of a sclerenchymatous layer, starch grains and crystal sand in the stem; and the presence of phenolic compounds in the epidermis, phloem and xylem of the midrib, petiole and stem.

Acknowledgments: The authors would like to thank the Electron Microscopy Center of the C-LABMU at the State University of Ponta Grossa for providing the FEG-SEM images. The bed bug research is supported by USDA-Discovery \& Development of Natural Products based insect management for medical, veterinary \& Urban (58-6066-6-043).

Conflicts of Interest: "The authors declare no conflict of interest." "The funders had no role in the design of the study; in the collection, analyses, or interpretation of data; in the writing of the manuscript, or in the decision to publish the results".

\section{REFERENCES}

1. The Plant List. A working list of all plant species [Internet]. [place unknown: publisher: unknown]; [updated 2020 Mar 03; cited 2020 Mar 03] Available from: www.theplantlist.org/1.1/browse/A/Lauraceae/Ocotea/.

2. Ocotea in Flora do Brasil 2020 em construção. [Jardim Botânico do Rio de Janeiro]; [updated 2020 Mar 03; cited 2020 Mar 03]. Available from: http://floradobrasil.jbrj.gov.br/reflora/floradobrasil/FB8440.

3. Vattimo-Gil I. Contribuição ao conhecimento da distribuição geográfica das Lauraceae VII. Rodriguésia. 1980 Jul;32(54):351-367. doi:10.1590/2175-78601980325419.

4. Rohwer JG. Prodromus einer Monographie der Gattung Ocotea Aubl. (Lauraceae), sensu lato. Mitt Inst Allg Bot Hamburg. 1986 Apr;20:3-278.

5. Garrett R, Romanos MTV, Borges RM, Santos MG, Rocha L, Silva AJR. Antiherpetic activity of a flavonoid fraction from Ocotea notate leaves. Rev Bras Farmacogn. 2012 Mar;22(2):306-313. doi:10.1590/S0102695X2012005000003.

6. Costa IFB, Calixto SD, Araujo MH, Konno TUP, Tinoco LW, Guimarães DO, Lasunskaia EB, Leal IRC, Muzitano MF. Antimycobacterial and nitric oxide production inhibitory activities of Ocotea notata from Brazilian restinga. Sci World J. 2015;947248:1-9. doi:10.1155/2015/947248.

7. Farago PV, Budel JM, Duarte MR, Nakashima T. Análise morfoanatômica de folhas de Ocotea puberula (Rich.) Nees, Lauraceae. Rev Bras Farmacogn. 2005 Jul;15(3):250-255. doi:10.1590/S0102-695X2005000300016.

8. Montrucchio DP, Miguel OG, Zanin SMW, Silva GA, Cardozo AM, Santos ARS. Antinociceptive effects of a chloroform extract and the alkaloid dicentrine isolated from fruits of Ocotea puberula. Planta Med. 2012;78(14):15431548. doi:10.1055/s-0032-1315026.

9. Silva JK, Trindade R, Moreira EC, Maia JGS, Dosoky NS, Miller RS, Cseke LJ, Setzer WN. Chemical diversity, biological activity, and genetic aspects of three Ocotea species from the Amazon. Int J Mol Sci. 2017 May;18(5):10811095. doi:10.3390/ijms18051081.

10.Barbosa LCA, Filomeno CA, Teixeira RR. Chemical variability and biological activities of Eucalyptus spp. essential oils. Molecules. 2016 Dec;21(12):1671-1686. doi:10.3390/molecules21121671.

11.Conceição RS, Carneiro MMAA, Reis IMA, Branco A, Vieira IJC, Braz-Filho R, Botura MB. In vitro acaricide activity of Ocotea aciphylla (Nees) Mez. (Lauraceae) extracts and identification of the compounds from the active fractions. Ticks and Tick-borne Diseases. 2017 Feb;8(2):275-282. doi:10.1016/j.ttbdis.2016.11.013.

12.Ballabeni V, Tognolini M, Giorgio C, Bertoni S, Bruni R, Barocelli E. Ocotea quixos Lam. essential oil: In vitro and in vivo investigation on its anti-inflammatory properties. Fitoterapia. 2010 Jun;81(4)289-295. doi:10.1016/j.fitote.2009.10.002.

13.Fournet A, Ferreira ME, Arias AR, Guy I, Guinaudeau H, Heinzen H. Phytochemical and antiprotozoal activity of Ocotea lancifolia. Fitoterapia. 2007 Jul;78(5)382-384. doi:10.1016/j.fitote.2007.03.003.

14.Garcez FR, Silva AGR, Garcez WS, Linck G, Matos MCF, Santos ECS, Queiroz LMM. Cytotoxic aporphine alkaloids from Ocotea acutifolia. Planta Med. 2011 Oct;77(4)383-387. doi:10.1055/s-0030-1250401. 
15.Gontijo DC, Brandão GC, Gontijo PC, Oliveira AB, Diaz MAN, Fietto LG, Leite JPV. Identification of phenolic compounds and biologically related activities from Ocotea odorifera aqueous extract leaves. Food Chem. 2017 Sep;230:618-626. doi:10.1016/j.foodchem.2017.03.087.

16. Chaverri C, Cicció JF. Essential oil of trees of the genus Ocotea (Lauraceae) in Costa Rica. I. Ocotea brenesii. Rev Biol Trop. 2005 Sep;53:431-436. doi:10.15517/rbt.v53i3-4.14611.

17. Takaku S, Haber WA, Setzer WN. Leaf essential oil composition of 10 species of Ocotea (Lauraceae) from Monteverde, Costa Rica. Biochem Syst Ecol. 2007 Aug;35(8):525-532. doi:10.1016/j.bse.2007.02.003.

18.Vilegas JHY, Gottlieb OR, Kaplan MA, Gottlieb HE. Aporphine alkaloids from Ocotea caesia. Phytochemistry. 1989;28(12):3577-3578. doi:10.1016/0031-9422(89)80403-0.

19.Dias CS, Silva IG, Cunha EVL, Silva MS, Braz-Filho R, Barbosa-Filho JM. Isolamento e identificação de novos alcalóides de Ocotea duckei Vattimo (Lauraceae). Rev Bras Farmacogn. 2003;13(1 Suppl):62-63. doi:10.1590/S0102-695X2003000300023.

20.Morais LCSL, Almeida RN, Cunha EVL, Silva MS, Barbosa-Filho JM, Gray Al. Further lignans from Ocotea duckei. Pharm Biol. 1999;37(2):144-147. doi:10.1076/phbi.37.2.144.6084.

21. Amato $\mathrm{CM}$. Ecologia de populações de Ocotea porosa (Nees) Barroso em áreas submetidas a diferentes graus de perturbação [dissertation]. Curitiba: Universidade Federal do Paraná Curitiba; 2008. 49 p.

22.Johansen DA. Plant microtechnique. New York: McGraw Hill Book; 1940. 523 p.

23.Berlyn GP, Miksche JP. Botanical microtechnique and cytochemistry. lowa: The lowa State University Press; 1976.

24. O'Brien TP, Feder N, McCully ME. Polychromatic staining of plant cell walls by Toluidine Blue O. Protoplasma. 1964 Jul;59:368-373. doi:10.1007/BF01248568.

25.Roeser KR. Die nadel der schwarzkiefer-massenprodukt und kunstwerk der natur. Mikrokosmos. 1962;61:33-36.

26. Kraus JE, Arduin M. Manual básico de métodos em morfologia vegetal. Rio de Janeiro: EDUR; 1997. p. 159-165.

27.Justus B, Almeida VP, Gonçalves MM, Assunção DPSF, Borsato DM, Arana AFM, Maia BHLNS, Paula JFP, Budel JM, Farago PV. Chemical composition and biological activities of the essential oil and anatomical markers of Lavandula dentata L. cultivated in Brazil. Braz Arch Biol Technol. 2018 Nov;61:1-12. doi:10.1590/1678-43242018180111.

28.Gabe M. Techniques Histologiques. Paris: Masson \& Cie; 1968. 704 p.

29.Sass JE. Botanical microtechnique. 3rd ed. Ames: The lowa State College Press; 1958. 228 p.

30.Foster AS. Practical plant anatomy. 2nd ed. Princeton: D. Van Nostrand; 1949. 228 p.

31. Adams RP. Identification of Essential Oil Components by Gas Chromatography/Mass Spectrometry. 4th ed. Illinois: Carol Stream; 2007. 804 p.

32. Mosmann T. Rapid colorimetric assay for cellular growth and survival: application to proliferation and cytotoxicity assays. J Immunol Methods. 1983 Dec;65(1-2):55-63. doi:10.1016/0022-1759(83)90303-4.

33.Santos M, Oliveira PL. Aspectos anatômicos do pecíolo de quatro espécies do gênero Ocotea Aubl. (Lauraceae) ocorrentes no Rio Grande do Sul. INSULA Revista de Botânica. 1995;24:3-14.

34.Farago PV, Paula JP, Nakashima T, Döll-Boscardin P, Budel JM, Maia BHLNS. Chemical composition and antibacterial activity of the essential oil from bark of Ocotea puberula (Rich.) Ness. Lat Am J Pharm. 2010 Mar;29(7):1242-1245.

35.Gonçalves RA, Pinheiro AB, Oliveira MA, Nascimento RT, Rosalem PF, Garcia VL, Martins AR. Anatomical characters and chemical profile of leaves of three species in Lauraceae family. Rev Bras Farmacogn. 2018 Jan;28(1):1-8. doi:10.1016/j.bjp.2017.11.008.

36. Coutinho DF, Agra MF, Barbosa-Filho JM, Basílio IJLD. Morfo-anatomia foliar de Ocotea gardneri (Meisn.) Mez (Lauraceae-Lauroideae). Rev Bras Farmacogn. 2006 Apr;16(2):178-184. doi:10.1590/S0102-695X2006000200008.

37. Toledo MGT. Estudo botânico e fitoquímico de Ocotea odorifera (Vell.) Rohwer. (Lauraceae) da região metropolitana de Curitiba [dissertation]. Curitiba: Universidade Federal do Paraná; 2000. 62 p.

38. Coutinho DF, Agra MF, Basílio IJLD, Barbosa-Filho JM. Estudo morfoanatômico das folhas de Ocotea duckei Vattimo (Lauraceae-Lauroideae). Rev Bras Farmacogn. 2006 Oct;16(4):537-544. doi:10.1590/S0102695X2006000400017.

39. Santos M, Oliveira PL. Aspectos anatômicos da lâmina foliar de Ocotea porosa (Nees et Mart. ex Nees) J. Angely (Lauraceae). INSULA Revista de Botânica. 1988;18:3-22.

40. Metcalfe CR, Chalk L. Anatomy of the Dicotyledones: leaves, stem and wood in relation to taxonomy with notes on economic uses. Oxford: Clarendon Press; 1972. 1500 p.

41. Wosch L, Imig DC, Cervi AC, Moura BB, Budel JM, Santos CAM. Comparative study of Passiflora taxa leaves: I. A morpho-anatomic profile. Rev Bras Farmacogn. 2015 Jul;25(4):328-343. doi:10.1016/j.bjp.2015.06.004. 
42. Almeida VP, Hirt AA, Raeski PA, Mika BE, Justus B, Santos VLP, Franco CRC, Paula JP, Farago PV, Budel JM. Comparative morphoanatomical analysis of Mikania species. Rev Bras Farmacogn. 2017 Jan;27(1):9-19. doi:10.1016/j.bjp.2016.05.002.

43. Chaverri C, Diaz C, Cicció JF. Chemical Analysis of Essential Oils from Ocotea gomezii W.C. Burger and Ocotea morae Gómez-Laur. (Lauraceae) Collected at "Reserva Biológica Alberto M. Brenes" in Costa Rica and their Cytotoxic Activity on Tumor Cell Lines. J Braz Chem Soc. 2011;22(4):741-745. doi:10.1590/S010350532011000400018.

44. Weyerstahl P, Wahlburg HC, Splittgerber U, Marschall H. Volatile Constituents of Brazilian Phoebe Oil. Flavour and Fragrance Journal. 1994 Jul;9(4):179-186. doi:10.1002/ffj.2730090407.

45. Reynolds T, Kite G. Volatile constituents of Brazilian Phoebe porosa Mez. J Essent Oil Res. 1995 Jul;7(4):415-418. doi:10.1080/10412905.1995.9698551.

46. Brito AFR. Análise de variação sazonal e das atividades antifúngica e antimicrobiana em óleos essenciais de Ocotea porosa (Nees) Barroso e Nectandra megapotamica (Spreng.) Menz [dissertation]. São Paulo: Instituto de Química; 2009. 121p.

47.Govindarajan M, Benelli G. Eco-friendly larvicides from Indian plants: Effectiveness of lavandulyl acetate and bicyclogermacrene on malaria, dengue and Japanese encephalitis mosquito vectors. Ecotoxicol Environ Saf. 2016 Nov;133:395-402. doi:10.1016/j.ecoenv.2016.07.035.

48.Koziol A, Stryjewska A, Librowski T, Salat K, Gawel M, Moniczewski A, Lochynski S. An overview of the pharmacological properties and potential applications of natural monoterpenes. Mini Rev Med Chem. 2014 Dec;14(14):1156-1168. doi:10.2174/1389557514666141127145820.

49. Özbek H, YImaz BS. Anti-inflammatory and hypoglycemic activities of alpha-pinene. Acta Pharm Sci. 2017;55(04):714. doi:10.23893/1307-2080.APS.05522.

50.Pinheiro MA, Magalhães RM, Torres DM, Cavalcante RC, Mota FSX, Coelho EMAO, Moreira HP, Lima GC, Araújo PCC, Cardoso JHL, Souza ANC, Diniz LRL. Gastroprotective effect of alpha-pinene and its correlation with antiulcerogenic activity of essential oils obtained from Hyptis. Pharmacogn Mag. 2015 Jan;11(41):123-130. doi:10.4103/0973-1296.149725.

51.Guzmán-Gutiérrez SL, Bonilla-Jaime H, Gómez-Cansino R, Reyes-Chilpa R. Linalool and $\beta$-pinene exert their antidepressant-like activity through the monoaminergic pathway. Life Sciences. 2015 May;128:24-29. doi:10.1016/j.lfs.2015.02.021.

52. Astani A, Schnitzler $P$. Antiviral activity of monoterpenes beta-pinene and limonene against herpes simplex virus in vitro. Iran J Microbiol. 2014 Jun;6(3)149-155.

53. Budel JM, Wang M, Raman V, Zhao J, Khan SI, Rehman JU, Techen N, Tekwani B, Monteiro LM, Heiden G, Takeda IJM, Farago PV, Khan IA. Essential Oils of Five Baccharis Species: Investigations on the Chemical Composition and Biological Activities. Molecules. 2018 Oct;23(10):2620-2639. doi:10.3390/molecules23102620.

54. Machado CD, Raman V, Rehman JU, Maia BHLNS, Meneghetti EK, Almeida VP, Silva RZ, Farago PV, Khan IA, Budel JM. Schinus molle: anatomy of leaves and stems, chemical composition and insecticidal activities of volatile oil against bed bug (Cimex lectularius). Rev Bras Farmacogn. 2018 Jan;29(1):1-10. doi:10.1016/j.bjp.2018.10.005.

55.Grecco SS, Martins EG, Girola N, Figueiredo CR, Matsuo AL, Soares MG, Bertoldo BC, Sartorelli P, Lago JHG. Chemical composition and in vitro cytotoxic effects of the essential oil from Nectandra leucantha leaves. Pharm Biol. 2015;53(1):133-137. doi:10.3109/13880209.2014.912238.

56. Ashley EA, Dhorda M, Fairhurst RM, et al. Spread of artemisinin resistance in Plasmodium falciparum malaria. $\mathrm{N}$ Engl J Med. 2014 Jul;371:411-423. doi:10.1056/NEJMoa1314981.

57.Pereira CB, Kanunfre CC, Farago PV, Borsato DM, Budel JM, Maia BHLNS, Campesatto EA, Sartoratto A, Miguel MD, Miguel OG. Cytotoxic mechanism Baccharis milleflora (Less.) DC. essential oil. Toxicol in Vitro. 2017 Aug;42:214-21. doi:10.1016/j.tiv.2017.04.031.

58. Justus B, Kanunfre CC, Budel JM, Faria MF, Raman V, Paula JP, Farago PV. New insights into the mechanisms of French lavender essential oil on non-small-cell lung cancer cell growth. Ind Crops Prod. 2019 Sep;136:28-36. doi:10.1016/j.indcrop.2019.04.051.

2020 by the authors. Submitted for possible open access publication under the terms and conditions of the Creative Commons Attribution (CC BY NC) license (https://creativecommons.org/licenses/by-nc/4.0/). 